\title{
First report of Strongyloides sp. (Nematoda, Strongyloididae) in Leopardus tigrinus (Carnivora: Felidae) in the municipality of Botucatu, State of Sáo Paulo, Brazil
}

\author{
Primeiro relato de Strongyloides sp. (Nematoda, Strongyloididae) em Leopardus tigrinus \\ (Carnivora: Felidae) do município de Botucatu, Estado de São Paulo, Brasil \\ Karina R. dos Santos ${ }^{1}$; Paula Faciulli²; Telma Paparotto ${ }^{3}$; Regina K. Takahira ${ }^{3}$; \\ Raimundo S. Lopes ${ }^{2}$; Reinaldo J. da Silva ${ }^{1 *}$
}

1Departamento de Parasitologia, Instituto de Biociências, Universidade Estadual Paulista - UNESP
${ }^{2}$ Departamento de Clínica Veterinária, Enfermidades Parasitárias dos Animais Domésticos,
Faculdade de Medicina Veterinária e Zootecnia - FMVZ, Universidade Estadual Paulista - UNESP
${ }^{3}$ Departamento de Clínica Veterinária, Laboratório Clínico Veterinário,
Faculdade de Medicina Veterinária e Zootecnia - FMVZ, Universidade Estadual Paulista - UNESP

Received February 19, 2008

Accepted May 28, 2009

\begin{abstract}
The present study reports the first case of infection by Strongyloides sp. in Leopardus tigrinus in the municipality of Botucatu, State of São Paulo, Brazil. Feces of the infected L. tigrinus specimen were cultivated in sterilized equine feces and a cat (Felis catus domesticus) was experimentally infected with three thousand infective $\mathrm{L}_{3}$ subcutaneous route, in order to identify the Strongyloides species involved in the parasitism. Parthenogenetic females recovered from the experimental animals were analyzed but comparison between the biometric data found and the data in the literature did not enable identification of the species. This is the first report on the occurrence of Strongyloides sp. in L. tigrinus.
\end{abstract}

Keywords: Leopardus tigrinus, wild felids, parasitic infection, disease, new host.

\section{Resumo}

O presente estudo reporta o primeiro caso de infecção por Strongyloides sp. em Leopardus tigrinus no município de Botucatu, Estado de São Paulo, Brasil. Fezes do exemplar parasitado de L. tigrinus foram cultivadas em fezes eqüinas esterilizadas e foi realizada infecçáo experimental em gato (Felis catus domesticus) com três mil larvas $\mathrm{L}_{3}$ infectantes por via subcutânea, para a identificação da espécie de Strongyloides envolvida no parasitismo. As fêmeas partenogenéticas obtidas do animal experimental foram analisadas porém a comparaçáo dos dados biométricos encontrados com os dados da literatura não permitiu a identificação da espécie. Este é o primeiro relato sobre a ocorrência de Strongyloides sp. Em L. tigrinus

Palavras-chave: Leopardus tigrinus, felídeos selvagens, infecção parasitária, doença, novo hospedeiro.

The genus Strongyloides includes 52 parasite species that infect numerous vertebrates, such as snakes, felids, canids and ruminants (DORRIS et al., 2002). In Brazil, several Strongyloides species have been reported, infecting a wide diversity of hosts. These include S. chapini, S. ferreirai, S. fuelleborni, S. myopotami, S. papillosus, S. ransomi, S. ratti, S. stercoralis, S. vezezuelensis and S. westeri, which were found in mammals (VICENTE et al., 1997).

Strongyloides spp. have been described worldwide in felids. There are reports of $S$. planiceps in tigers in Malaysia and in

*Corresponding author: Reinaldo J. da Silva

Departamento de Parasitologia, Instituto de Biociências,

Universidade Estadual Paulista - UNESP,

Distrito de Rubião Júnior s/n, CEP 18618-000 Botucatu - SP, Brasil

e-mail: reinaldo@ibb.unesp.br domestic cats in Japan; S. felis in domestic cats in Calcutta, India, and in Australia; and S. tumefaciens in domestic cats in the USA (Louisiana, Florida, Texas and Georgia) and in Felis chaus (jungle cat) in India, Felis rufus (bobcat) and Felis concolor coryi (Florida panther) in Florida (BOWMAN et al., 2002). In Brazil, S. stercoralis has also been found in domestic cats (Felis catus domesticus) (VICENTE et al., 1997). However, there are no reports on the occurrence of Strongyloides spp. in the little spotted cat (Leopardus tigrinus).

The aim of this study was to report the first case of Strongyloides sp. in this felid species.

In the municipality of Botucatu, State of São Paulo, Brazil, a male of the species $L$. tigrinus was cared for at the Veterinary Hospital, Faculdade de Medicina Veterinária e Zootecnia, Universidade 
Estadual Paulista Julio de Mesquita Filho, Botucatu, after it was run over by a motor vehicle. Coproparasitological examinations revealed the presence of embryonated eggs in its feces. Cultures on the feces demonstrated the presence of L3 larvae with a notched tail, which is a characteristic of the genus Strongyloides.

In order to identify the Strongyloides species involved in this parasitism, experimental infection in a domestic cat (F. catus domesticus) was conducted subsequently. For this, samples of the L. tigrinus feces were cultivated in sterilized equine feces and maintained in an incubator at $25^{\circ} \mathrm{C}$ and $80 \%$ humidity, for seven days.

The material was analyzed under a microscope in order to detect any third-stage filariform larvae. These larvae were collected using Baerman's method. About 17,000 larvae were thus obtained to experimentally infect a domestic cat (a 30-day-old female). This animal had previously treated with antihelminthic drugs and coproparasitological examinations had been performed to confirm that it was free from helminth infection.

Three thousand infective (L3) larvae were inoculated subcutaneously in this animal. After inoculation, fecal flotation
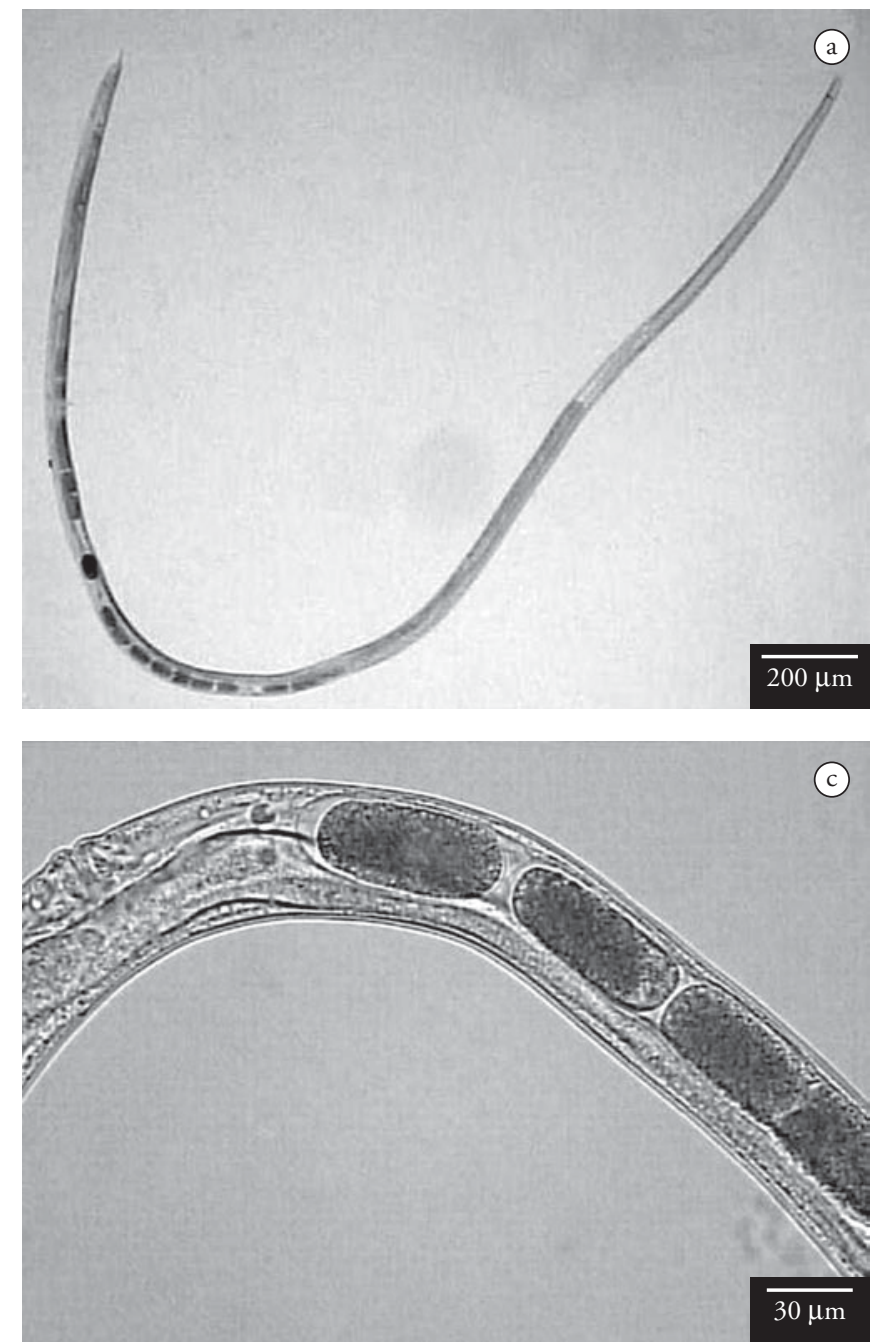

examinations were successively performed until the feces become positive for embryonated eggs. The cat was then sacrificed and parthenogenetic female were recovered. In order to obtain free-living males and females, cultures with feces from domestic cats were made, but no positive results were obtained.

Biometric analyses on both the parthenogenetic females and the eggs were performed using a computerized image analysis system (Qwin Lite 3.1; Leica). The results presented below are expressed as means and ranges (minimum and maximum).

The measurements on the parthenogenetic females were as follows $(\mathrm{n}=6$; Figure 1): total length 3,561 $\mu \mathrm{m}(3,314-3,966)$; maximum width $48 \mu \mathrm{m}$ (42-52); esophagus $753 \mu \mathrm{m}$ (728-784) in length and $21.2 \%(19.7-22.3)$ of total body length; vulva $1251 \mu \mathrm{m}$ $(1,194-1,338)$ from the anterior extremity; tail $33 \mu \mathrm{m}$ (28-36); eggs (inside the uterus) $71 \mu \mathrm{m}$ (58-84) in length and $29 \mu \mathrm{m}$ (24-36) in width. Comparison of this biometric data with the data in the literature did not enable identification of the species.

The present study reports the first case of Strongyloides sp. in L. tigrinus. Other cases in domestic and wild felids have been
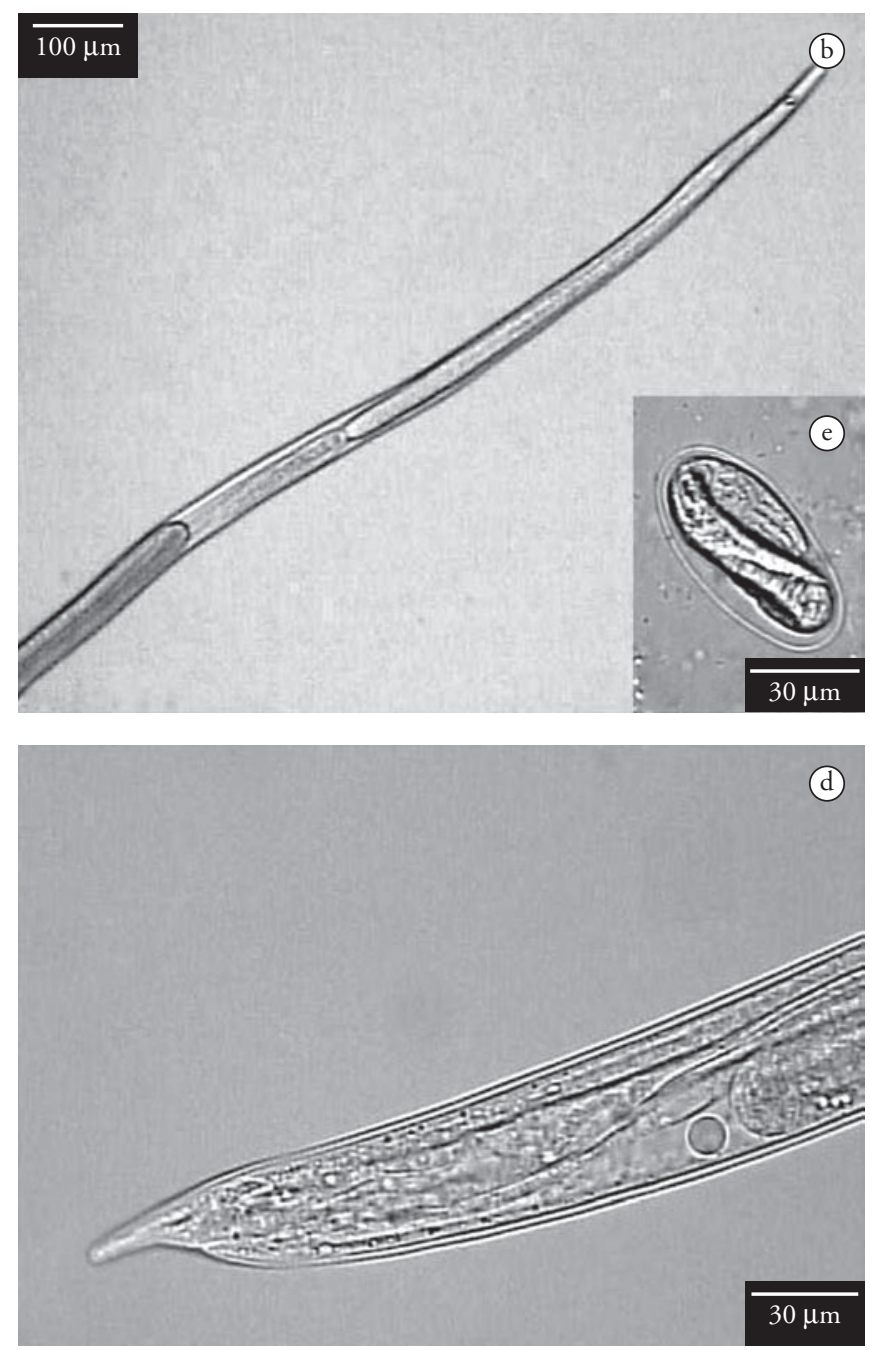

Figure 1. Strongyloides sp. collected from the small intestine of Felis catus domesticus after experimental infection with Strongyloides infective larvae (L3) obtained from culturing of Leopardus tigrinus feces: a) general view; b) Detail of the esophagus, initial portion of the intestine and ovary; c) Detail of vulva and uterus with eggs; d) Detail of tail and anus; and e) egg. 
reported (VICENTE et al., 1997; BOWMAN et al., 2002), but this is a rare finding. Oliveira and Cassaro (1999) reported that because wild felids have solitary habits and most of them are predominantly nocturnal, field observations are scarce and, thus, few data about their biology are available.

An experimental infection was conducted in order to identify the Strongyloides species found in this L. tigrinus individual because no parthenogenetic female could be recovered from this host, since the animal was reintroduced to the environment after proper medical treatment. The attempted use of another host in the same family for experimental infection produced positive results, since parthenogenetic females were recovered from the domestic cat used in this experiment. However, from the three thousand infective larvae inoculated, only six parthenogenetic females were recovered. In addition, no free-living males or females were recovered from the feces cultures.

Since a low percentage of the larvae completed the biological cycle, few parthenogenetic adult females were recovered. This may have been either because F. catus domesticus is not the specific host for the nematode that was examined, or because the felid immune system was able to react, thereby expelling these larvae (through IgA, which activates the eosinophils) (OLIVEIRA SEQUEIRA, 2000; CLAEREBOUT, 2000; SOULSBY, 1987). In addition, since the host was not specific, the growth and morphology of the parthenogenetic Strongyloides females might have undergone changes, thus causing difficulties for parasite species identification (OLIVEIRA SEQUEIRA, 2000; CLAEREBOUT, 2000; SOULSBY, 1987).

Other helminths have been reported infecting L. tigrinus. Hungria (1978) reported an occurrence of Toxascaris leonina (Hungria, 1978) in L. tigrinus in Venezuela. Eggs of Capillaria sp., Ancylostoma sp., Trichuris sp. and Toxocara sp. and adults of Vigosospirura potekhina, Didelphonema longispiculata, Pterygodermatites cahirensis, Trichuris campanula, Ancylostoma tubaeforme and Toxocara cati have also been reported in this felid species by Beldomenico (2005). However, there are no reports on occurrences of a Strongyloides spp. infecting L. tigrinus. Thus, this felid is a new host recorded for Strongyloides sp. These data reinforce the importance of the present report, which contributes towards knowledge of the helminth fauna of wild felids in Brazil.

\section{Acknowledgement}

The authors are indebted to Betina Metzger for her assistance with the English review.

\section{References}

BELDOMENICO, P. M.; KINSELLA, J. M.; UHART, M. M. Helminths of Geoffroy's cat, Oncifelis geoffroyi (Carnivora, Felidae) from the Monte desert, central Argentina. Acta Parasitologica, v. 50, n. 3, p. 263-266, 2005.

BOWMAN, D. D. et al. Feline clinica parasitology. Ames: Iowa State University Press, 2002. p. 469.

CLAEREBOUT, E.; VERCRUYSSE, J. The immune response and the evaluation of acquired immunity against gastrointestinal nematodes in cattle: a review. Parasitology, v. 120, n. S25-S42, p. 25-42, 2000.

DORRIS, M.; VINEY, E. M.; BLAXTER, L. M. Molecular phylogenetic analysis of the genus Strongyloides and related nematodes. Internacional Journal for Parasitology, v. 32, n. 12, p. 1507-1517, 2002.

HUNGRÍA, C. D. Helmintos parasitos de vertebrados em el estado zulia (Venezuela) algunas espécies nuevas para Venezuela. Veterinária Tropical, v. 3, n. 1, p. 15-37, 1978.

OLIVEIRA-SEQUEIRA, T. C. G.; AMARANTE, A. F. T.; SEQUEIRA, J. L. Parasitological caracteristics and tissue response in the abomasum of sheep infected with Haemonchus spp. Arquivos Brasileiro de Medicina Veterinária e Zootecnia, v. 52, n. 5, p. 447-452, 2000.

OLIVEIRA, T. G.; CASSARO, K. Guia de identificaçáo dos felinos brasileiros. 2 ed. Sáo Paulo: Sociedade de Zoológicos do Brasil, 1999. $60 \mathrm{p}$.

SOULSBY, E. J. P. Immune response in parasitic infections: immunology, immunopathology and immunoprophylaxis. Boca Raton: CRC, 1987.336 p. (v. 1)

VICENTE, J. J. et al. Nematóides do Brasil. Parte V: Nematóides de mamíferos. Revista Brasileira de Zoologia, v. 14, Suppl. 1, p.1-452, 1997. 